\title{
Analisis Promosi Kenaikan Jabatan Berdasarkan Evaluasi Kinerja Pegawai
}

\author{
Analysis of Job Promotion Based on Performance Evaluation
}

\author{
Lili Tanti \\ Universitas Potensi Utama \\ E-mail: lili@potensi-utama.ac.id atau lili_tantiai@yahoo.co.id
}

\begin{abstract}
Abstrak
Sumber daya manusia di dalam suatu organisasi perusahaan merupakan hal yang sangat penting untuk mendukung kemajuan dan kualitas perusahaan dalam mencapai tujuan. Kenaikan jabatan merupakan suatu faktor yang sangat penting bagi perencanaan karir pegawai dan juga untuk meremajakan suatu posisi jabatan agar diduduki oleh seseorang yang mempunyai kriteriakriteria yang cocok. Untuk itu perlu diterapkan salah satu metode didalam sistem pendukung Keputusan didalam memilih pegawai yang cocok sesuai dengan kriteria dilingkungan Universitas Potensi Utama yaitu aspek penilaian umum, aspek penguasaan bidang kerja dan aspek perilaku. Sehingga dengan penerapan metode profile matching didalam system pendukung keputusan dalam proses evaluasi kinerja pegawai diharapkan dapat menentukan urutan prioritas pegawai, yang digunakan untuk membantu pihak manajemen dalam membuat keputusan untuk promosi kenaikan jabatan pegawai yang dinilai berdasarkan evaluasi kinerja pegawai dengan profil jabatan
\end{abstract}

Kata Kunci — DSS, Kenaikan Jabatan, Profile Matching.

\begin{abstract}
Human resources within an enterprise organization is very important to support the progress and quality of the company in achieving its objectives. Promotion is a very important factor for employee career planning and also to rejuvenate a job position that was occupied by someone who has the matching criteria. For it is necessary to apply one of the methods within the Decision Support system in choosing a suitable employee in accordance with the criteria of the environment of the University Main Potential namely general assessment aspects, aspects of the mastery of work and behavioral aspects. So with the application profile matching method in the decision support system in the employee performance evaluation process is expected to determine the priority order of employees, which is used to assist management in making decisions for the promotion of employee promotions were assessed based on performance evaluation of employees with occupational profiles.
\end{abstract}

Keywords - DSS, performance Lecturer, Promethee.

\section{PENDAHULUAN}

Sumber daya manusia di dalam suatu organisasi perusahaan merupakan hal yang sangat penting untuk mendukung kemajuan dan kualitas perusahaan dalam mencapai tujuan. Kenaikan jabatan merupakan suatu faktor yang sangat penting bagi perencanaan karir pegawai dan juga untuk meremajakan suatu posisi jabatan agar diduduki oleh seseorang yang mempunyai kriteriakriteria yang cocok untuk menempati suatu jabatan yang diusulkan [1]. Pengisian jabatan yang kosong pada proses kenaikan jabatan sring mengalami kesulitan karena pengajuan calon kandidat 
yang bisa menempati jabatan tersebut dengan cara pencocokan profil karyawan dan profil jabatan kurang terdefinisi dengan baik [2].

Profile matching adalah sebuah mekanisme pengambilan keputusan dengan mengasumsikan bahwa terdapat tingkat variabel prediktor yang ideal yang harus dimiliki oleh pelamar, bukannya tinggkat minimal yang harus dipenuhi atau dilewati. Dalam pencocokan profil, dilakukan identifikasi terhadap kelompok karyawan yang baik maupun buruk. Para karyawan dalam kelompok tersebut diukur menggunakan beberapa kriteria penilaian. Aspekaspek Penilaian Sistem pendukung keputusan tersebut dirancang sedemikian rupa sehingga pengguna yang dalam hal ini adalah manajer bagian sumber daya manusia bisa menentukan aspek-aspek penilaian sendiri secara dinamis sehingga sistem pendukung keputusan tersebut bisa dipakai lebih luas [3]

Adapun penelitian yang terkait adalah (1) menurut Kusrini \& Awaluddin, masalah yang sering terjadi dalam proses penilaian kinerja karyawan diantaranya adalah subyektifitas pengambilan keputusan, terutama jika beberapa karyawan yang ada memiliki kemampuan yang tidak jauh berbeda. Penggunaan sistem pendukung keputusan, diharapkan mengurangi subyektifitas dalam pengambilan keputusan. Sebagai gantinya akan dilakukan perhitungan terhadap seluruh kriteria untuk seluruh karyawan, sehingga diharapkan karyawan dengan kemampuan terbaiklah yang terpilih [8]. (2) Menurut bahtiar imam rosadi dalam penelitiannya menyebutkan bahwa Metode profile matching ini dilakukan karena sesuai dengan masalah yang di hadapi dalam memilih karyawan yang sesuai dan berkompeten dengan profile jabatan yang di promosikan oleh perusahaan tersebut. Sistem Kenaikan Jabatan dan Perencanaan Karir yang digunakan berdasar pada 3 variabel, yaitu; ilmu Pengetahuan dan Budaya Perusahaan, Kemampuan Individu, serta Kepribadian Individu. [9]

Berdasarkan hal tersebut, maka sangat diperlukan suatu sistem pendukung keputusan dalam proses kenaikan jabatan di lingkungan Universitas Potensi Utama dimana dinilai berdasarkan evaluasi kinerja pegawai dengan menerap metode profile matching. Adapun aspek yang menjadi penilaian adalah aspek umum, bidang kerja dan prilaku.

Tujuan penelitian ini adalah untuk menentukan urutan prioritas pegawai, yang digunakan untuk membantu pihak manajemen dalam membuat keputusan untuk promosi kenaikan jabatan pegawai yang dinilai berdasarkan evaluasi kinerja pegawai dengan profil jabatan.

\section{METODE PENELITIAN}

Diagram Alur Penelitian dalam promosi kenaikan jabatan berdasarkan evaluasi kinerja pegawai ditunjukkan pada Gambar 1.

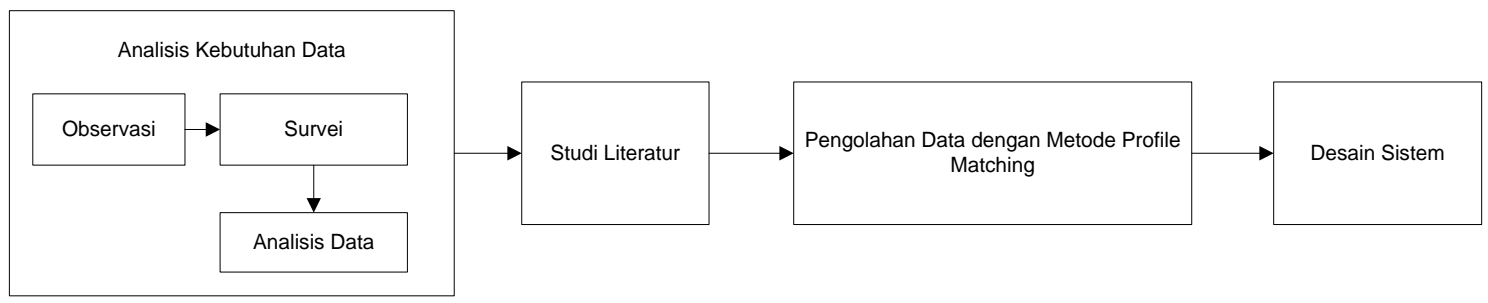

Gambar 1. Diagram Alur Penelitian

Proses pembuatan sistem pendukung keputusan evaluasi kinerja pegawai untuk promosi jabatan dilingkungan Universitas Potensi Utama dengan tahapan sebagai berikut:

1. Analisa Kebutuhan Sistem

Analisa kebutuhan sistem dilakukan dengan cara observasi, survey dan analisis kebutuhan data. Pengolahan data penilaian kinerja pegawai sudah dilakukan secara terkomputerisasi, tetapi belum adanya suatu sistem yang memberikan rekomendasi kepada pihak pimpinan untuk menentukan siapa pegawai yang layak untuk memegang jabatan dilingkungan 
Universitas Potensi Utama. Dengan adanya analisa ini, penulis mencari solusi yang tepat untuk mengatasi masalah yang terjadi pada perusahaan, yaitu membangun sebuah sistem pendukung keputusan penilaian kinerja pegawai dengan penerapan metode profil matching, dimana metode profil Proses secara garis besar merupakan proses membandingkan antara kompetensi seorang pegawai ke dalam kompetensi jabatan sehingga dapat diketahui perbedaan kompetensinya (disebut juga gap). Semakin kecil gap yang dihasilkan maka bobot nilainya semakin besar, yang berarti memiliki peluang lebih besar bagi seorang calon pegawai untuk bisa diterima [5].

Data yang digunakan sebagai alaternatif yaitu data pegawai dan data kriteria yang dijadikan sebagai acuan didalam proses penilaian sekaligus promosi kenaikan jabatan dilingkungan Universitas Potensi Utama adalah

a. Penilaian Umum

Penilaian umum meliputi disiplin kerja, disiplin administrasi, keandalan, kedewasaan dan integritas pribadi, semangat kerja, komunikasi dan kerjasama.

b. Penguasaan Bidang Kerja

Penguasaan bidang kerja meliputi keteguhan pada prinsip kerja, kuantitas hasil kerja, kualitas hasil kerja, kuantitas hasil kerja, kepedulian terhadap organisasi.

c. Prilaku

Prilaku meliputi kekuasaan, pengaruh, keteguhan hati dan pemenuhan

\section{Studi Literatur}

Tahap ini bertujuan untuk memperdalam dan memahami mengenai teori maupun metode yang akan digunakan dalam memecahkan permasalahan yang ada. Studi literatur dilakukan dengan mencari literatur yang dipelajari pada tahap ini adalah mengenai metode profile matching dan proses promosi untuk kenaikan jabatan berdasarkan evaluasi kinerja pegawai.

\section{Pengolahan Data}

Tahap ini bertujuan untuk melakukan proses pengolahan data dari hasil data yang didapat dari tahap analisis kebutuhan data dan diolah dengan menggunakan metode profile matching.

\section{Perancangan Sistem}

Proses perancangan sistem meliputi perancangan dengan menggunakan UML (Unified Modeling Language). Unified Modeling Language (UML) adalah standar de-facto untuk pemodelan objek dan sistem perangkat lunak berorientasi. UML menyediakan diagram untuk mewakili sifat statis serta perilaku dinamis dari suatu sistem [4].

\subsection{Metode Profile Matching}

Metode profile matching atau pencocokan profil adalah metode yang sering sebagai mekanisme dalam pengambilan keputusan dengan mengasumsikan bahwa terdapat tingkat variabel prediktor yang ideal yang harus dipenuhi oleh subyek yang diteliti, bukannya tingkat minimal yang harus dipenuhi atau dilewati [6].

Untuk menganalisis pegawai yang sesuai dengan jabatan tertentu dilakukan dengan metode profile matching, dimana dalam proses ini terlebih dahulu kita menentukan kompetensi (kemampuan) yang diperlukan oleh suatu jabatan. Dalam proses profile matching secara garis besar merupakan proses membandingkan antara kompetensi individu ke dalam kompetensi jabatan sehingga dapat diketahui perbedaan kompetensinya (disebut juga gap) [7]. 
Langkah-langkah metode Profile Matching [3] adalah

1. Langkah pertama menentuan Bobot Nilai Gap. Pada tahap ini, akan ditentukan bobot nilai masingmasing aspek dengan menggunakan bobot nilai yang telah ditentukan bagi masingmasing aspek itu sendiri. Adapun inputan dari proses pembobotan ini adalah selisih dari profil pegawai dan profil jabatan.

2. Langkah kedua dengan melakukan pemetaan Gap. Gap yang dimaksud adalah perbedaan antara profil jabatan dengan profil karyawan.

$$
\text { GAP }=\text { Profil Pegawai }- \text { Profil Jabatan }
$$

3. Langkah ketiga dengan melakukan pencocokan dengan tabel bobot Gap Hasil Gap dari pengurangan profil pegawai dan profil jabatan bila dicocokkan dengan kolom selisih gap pada tabel bobot nilai yang dihasilkan sama yang ditunjukkan pada Tabel 1 .

Tabel 1. Bobot Nilai GAP

\begin{tabular}{|c|c|l|}
\hline Selisih & Bobot Nilai & \multicolumn{1}{|c|}{ Keterangan } \\
\hline $\mathbf{0}$ & $\mathbf{5}$ & Tidak ada selisih (kompetensi sesuai dg yg dibutuhkan) \\
\hline $\mathbf{1}$ & $\mathbf{4 , 5}$ & Kompetensi individu kelebihan 1 tingkat \\
\hline $\mathbf{- 1}$ & $\mathbf{4}$ & Kompetensi individu kekurangan 1 tingkat \\
\hline $\mathbf{2}$ & $\mathbf{3 , 5}$ & Kompetensi individu kelebihan 2 tingkat \\
\hline $\mathbf{- 2}$ & $\mathbf{3}$ & Kompetensi individu kekurangan 2 tingkat \\
\hline $\mathbf{3}$ & $\mathbf{2 , 5}$ & Kompetensi individu kelebihan 3 tingkat \\
\hline $\mathbf{- 3}$ & $\mathbf{2}$ & Kompetensi individu kekurangan 3 tingkat \\
\hline $\mathbf{4}$ & $\mathbf{1 , 5}$ & Kompetensi individu kelebihan 4 tingkat \\
\hline $\mathbf{- 4}$ & $\mathbf{1}$ & Kompetensi individu kekurangan 4 tingkat \\
\hline
\end{tabular}

4. Langkah keempat dengan melakukan perhitungan core factor dan secondary factor. Setelah menentukan bobot nilai gap untuk ketiga aspek yang dibutuhkan, kemudian tiap aspek dikelompokkan lagi menjadi dua kelompok yaitu core factor dan secondary factor.

a. Core factor merupakan aspek (kompetensi) yang paling menonjol/paling dibutuhkan oleh suatu jabatan yang diperkirakan dapat menghasilkan kinerja optimal. Untuk menghitung core factor digunakan persamaan 2 .

$\mathrm{NCF}=\frac{\sum \mathrm{NC}(\mathrm{i}, \mathrm{s}, \mathrm{p})}{\sum \mathrm{IC}}$

Keterangan:

NCF: Nilai rata-rata core factor

$\mathrm{NC}(\mathrm{i}, \mathrm{s}, \mathrm{p})$ : Jumlah total nilai core factor (kecerdasan, sikap kerja, perilaku)

IC: Jumlah item core factor

b. Secondary factor adalah item item selain aspek yang ada pada core factor. Untuk menghitung secondary factor digunakan persamaan 3.

$\mathrm{NCS}=\frac{\sum \mathrm{NS}(\mathrm{i}, \mathrm{s}, \mathrm{p})}{\sum \mathrm{IS}}$

Keterangan:

NSF: Nilai rata-rata secondary factor

NS (i,s,p) : Jumlah nilai total secondary factor (kecerdasan, sikap kerja, perilaku)

IS : Jumlah item secondary factor 
5. Perhitungan Nilai Total

Dari hasil perhitungan dari tiap aspek di atas kemudian dihitung nilai total berdasar presentasi dari core dan secondary yang diperkirakan berpengaruh terhadap kinerja tiap-tiap profil dengan menggunakan rumus persamaan 4.

$$
\mathrm{N}(\mathrm{k}, \mathrm{s}, \mathrm{p})=(\mathrm{x}) \% \mathrm{NCF}(\mathrm{k}, \mathrm{s}, \mathrm{p} \mathrm{x}) \mathrm{x}(\mathrm{x}) \% \mathrm{NSF}(\mathrm{k}, \mathrm{s}, \mathrm{p})
$$

$$
\begin{array}{ll}
\begin{array}{l}
\text { Keterangan: } \\
(\mathrm{k}, \mathrm{s}, \mathrm{p})
\end{array} & : \text { (Kinerja, sikap kerja, perilaku) } \\
\mathrm{N}(\mathrm{k}, \mathrm{s}, \mathrm{p}) & \text { : Nilai total dari aspek } \\
\mathrm{NCF}(\mathrm{k}, \mathrm{s}, \mathrm{p}) & : \text { Nilai rata-rata corefactor } \\
\mathrm{NSF}(\mathrm{k}, \mathrm{s}, \mathrm{p}) & : \text { Nilai rata-rata secondary factor } \\
(\mathrm{x}) \% & : \text { Nilai persen yang diinputkan }
\end{array}
$$

\section{Perhitungan Penentuan Hasil Akhir/Ranking}

Hasil akhir dari proses ini adalah ranking dari kandidat yang diajukan untuk mengisi suatu jabatan tertentu. Penentuan ranking mengacu pada hasil perhitungan tertentu dengan menggunakan persamaan 5 .

$\mathrm{Ha}=(\mathrm{x}) \% \mathrm{Nk}+(\mathrm{x}) \% \mathrm{Ns}+(\mathrm{x}) \% \mathrm{~Np}$

Keterangan:

Ha : Hasil Akhir

$\mathrm{Nk} \quad$ : Nilai Kapasitas Kinerja

Ns : Nilai Sikap Kerja

$\mathrm{Np} \quad$ : Nilai Perilaku

(x)\% : Nilai Persen yang diinputkan

\subsection{Perancangan Sistem}

Perancangan secara umum menggunakan UML (Unified Modelling Langguage) yang terdiri dari Use case diagram, Activity diagram dan Sequence diagram.

1. Use Case Diagram Sistem Pendukung Keputusan Promosi Kenaikan Jabatan Pegawai.

Usecase diagram adalah diagram usecase yang digunakan untuk menggambarkan secara ringkas siapa yang menggunakan sistem dan apa saja yang bisa dilakukannya, dalam hal ini terdiri dari dua actor yaitu actor admin dan actor pimpinan. Aktor admin dapat mengolah data user, data pegawai, mengelola nilai profile dan menentukan bobot nilai GAP serta melakukan proses penilaian berdasarkan hasil evaluasi kinerja pegawai dan menghasilkan informasi mengenai promosi jabatan pegawai sebagaimana yang ditunjukkan pada Gambar 2. 


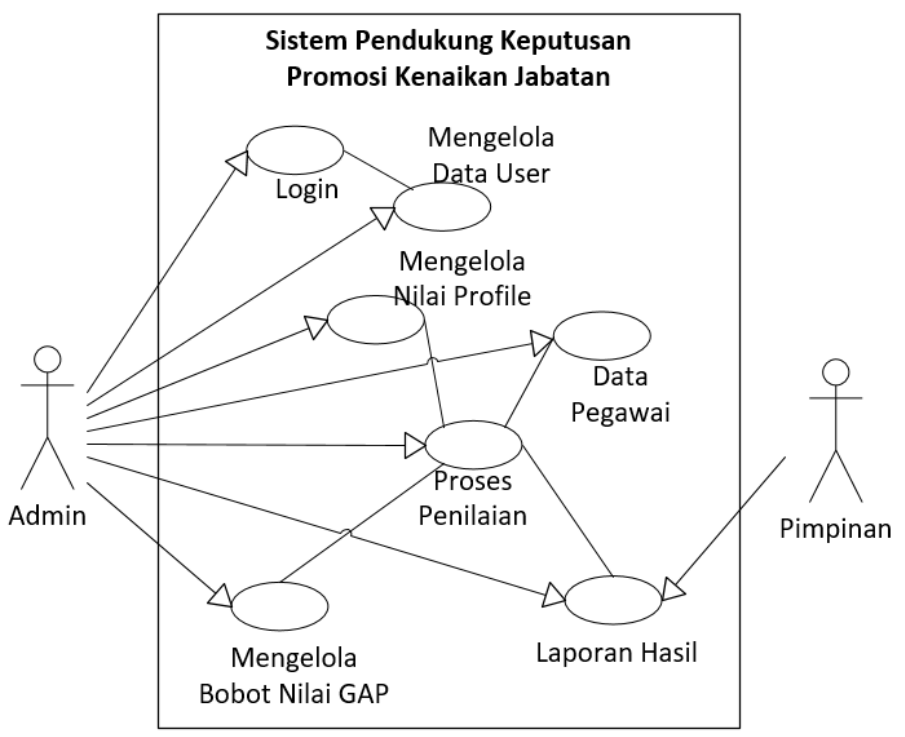

Gambar 2. Use Case Diagram Sistem Pendukung Keputusan Promosi Kenaikan Jabatan Pegawai

2. Activity dan Squence Diagram Sistem Pendukung Keputusan Promosi Kenaikan Jabatan Pegawai

Activity Diagram adalah alur logika dari setiap proses yang direncanakan, dimana activity ini akan menjelaskan proses penilaian dengan menggunakan metode profile matching sehingga diperoleh informasi mengenai promosi jabatan untuk pegawai yang ditunjukkan pada Gambar 3. Squence Diagram merupakan suatu diagram interaksi yang menggambarkan bagaimana objekobjek berpartisipasi dalam bagian interaksi (particular interaction) dan pesan yang ditukar dalam urutan waktu [4], dimana sequence diagram ini menjelaskan tentang proses penilaian untuk menghasilkan informasi untuk promosi kenaikan Jabatan yang ditunjukkan pada Gambar 4.

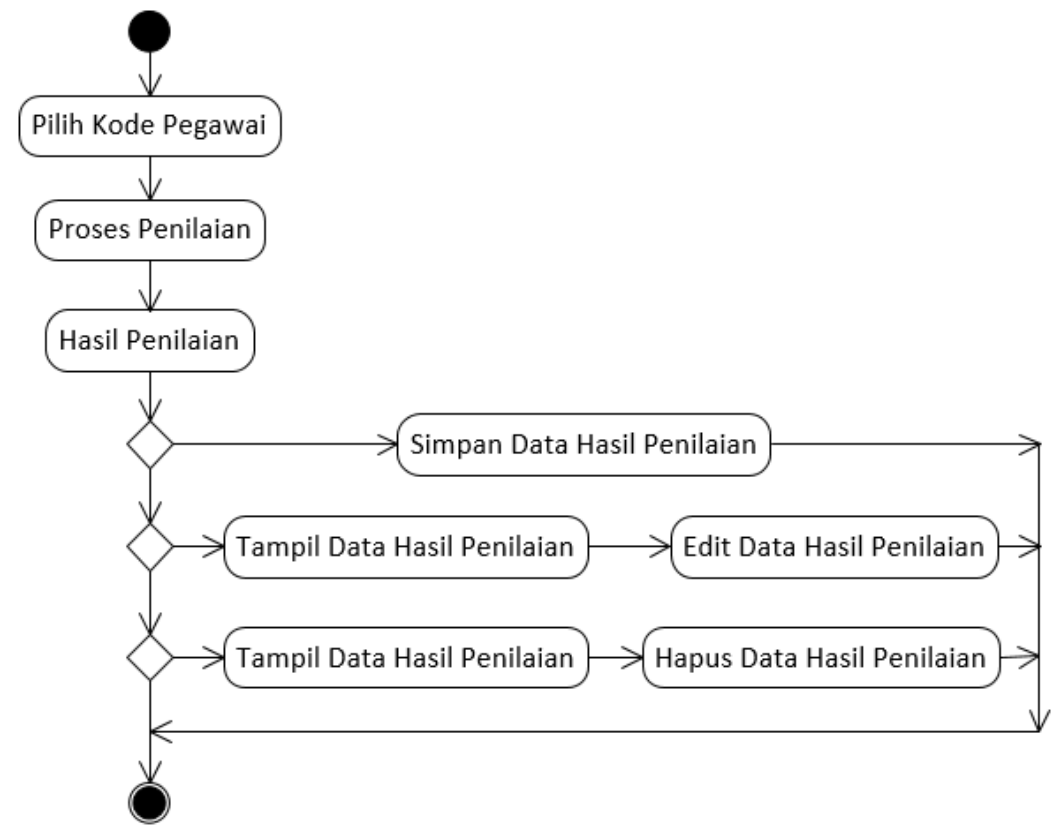

Gambar 3. Activity Diagram Proses Penilaian Promosi Kenaikan Jabatan Pegawai 
Citec Journal, Vol. 3, No. 4, Agustus 2016 - Oktober 2016

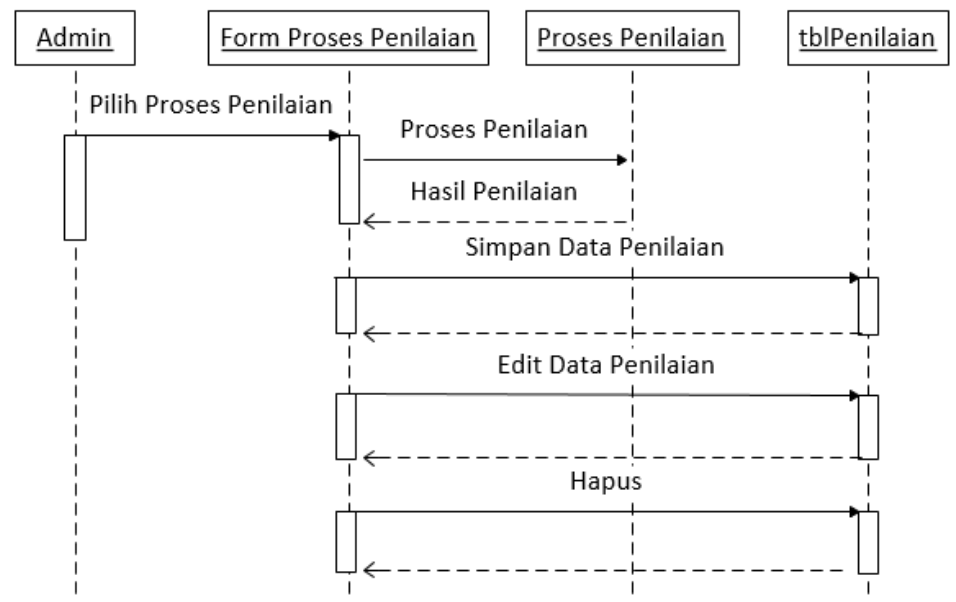

Gambar 4. Squence Diagram Proses Penilaian Promosi Kenaikan Jabatan Pegawai

\section{HASIL DAN PEMBAHASAN}

\subsection{Proses Penilaian}

Proses Penilaian dalam Proses Promosi Kenaikan Jabatan pegawai dilingkungan Universitas Potensi Utama dilakukan dengan penerapan metode profile matching dengan menggunakan tiga sampel pegawai.

\subsubsection{Perhitungan Nilai Tiap Kriteria}

Proses penilaian dalam proses promosi kenaikan jabatan diawali dengan penentuan bobot tiap aspek, dimana proses ini telah dilakukan dan ditetapkan oleh pihak manajemen.

a. Penilaian Umum

Penilaian umum meliputi disiplin kerja (A1), disiplin administrasi (A2), keandalan (A3), kedewasaan dan integritas pribadi (A4), semangat kerja (A5), komunikasi dan kerjasama (A6) yang ditunjukkan pada Tabel 2 dengan menggunakan rumus persamaan 1.

Tabel 2. Perhitungan GAP Penilaian Umum

\begin{tabular}{|c|c|c|c|c|c|c|c|c|}
\hline No & Pegawai & A1 & $\mathrm{A} 2$ & A3 & A4 & A5 & A6 & \\
\hline 1 & Pegawai-A & 2 & 4 & 3 & 3 & 2 & 2 & \\
\hline 2 & Pegawai-B & 3 & 4 & 3 & 3 & 2 & 3 & \\
\hline 3 & Pegawai-C & 4 & 4 & 3 & 3 & 4 & 3 & \\
\hline 4 & Pegawai-D & 3 & 5 & 4 & 3 & 4 & 4 & \\
\hline 5 & Pegawai-E & 3 & 3 & 3 & 1 & 2 & 5 & \\
\hline \multicolumn{2}{|c|}{ Profil Jabatan } & 3 & 4 & 4 & 3 & 4 & 3 & \multirow{6}{*}{ Gap } \\
\hline 1 & Pegawai-A & -1 & 0 & -1 & 0 & -2 & -1 & \\
\hline 2 & Pegawai-B & 0 & 0 & -1 & 0 & -2 & 0 & \\
\hline 3 & Pegawai-C & 1 & 0 & -1 & 0 & 0 & 0 & \\
\hline 4 & Pegawai-D & 0 & 1 & 0 & 0 & 0 & 1 & \\
\hline 5 & Pegawai-E & 0 & -1 & -1 & -2 & -2 & 2 & \\
\hline
\end{tabular}

b. Penguasaan Bidang Kerja

Penguasaan bidang kerja meliputi keteguhan pada prinsip kerja (B1), kuantitas hasil kerja (B2), kualitas hasil kerja (B3), kepedulian terhadap organisasi (B4) ditunjukkan pada Tabel 3 dengan menggunakan rumus persamaan 1 . 
Tabel 3. Perhitungan GAP Penguasaan Bidang Kerja

\begin{tabular}{|c|c|c|c|c|c|c|}
\hline No & Pegawai & B1 & B2 & B3 & B4 & \\
\hline 1 & Pegawai-A & 2 & 4 & 3 & 3 & \\
\hline 2 & Pegawai-B & 3 & 4 & 3 & 3 & \\
\hline 3 & Pegawai-C & 4 & 4 & 3 & 3 & \\
\hline 4 & Pegawai-D & 3 & 5 & 4 & 3 & \\
\cline { 1 - 6 } 5 & Pegawai-E & 3 & 3 & 3 & 1 & \\
\hline \multicolumn{2}{|c|}{ Profil Jabatan } & 3 & 5 & 5 & 4 & \multirow{2}{*}{ Gap } \\
\hline 1 & Pegawai-A & -1 & -1 & -2 & -1 & \\
\hline 2 & Pegawai-B & 0 & -1 & -2 & -1 & \\
\hline 3 & Pegawai-C & 1 & -1 & -2 & -1 & \\
\hline 4 & Pegawai-D & 0 & 0 & -1 & -1 & \\
\hline 5 & Pegawai-E & 0 & -2 & -2 & -3 & \\
\hline
\end{tabular}

c. Perilaku

Perilaku meliputi kekuasaan (C1), pengaruh (C2), keteguhan hati (C3) dan pemenuhan (C4) ditunjukkan pada Tabel 4 dengan menggunakan rumus persamaan 1.

Tabel 4. Perhitungan GAP Perilaku

\begin{tabular}{|c|c|c|c|c|c|c|}
\hline No & Pegawai & C1 & C2 & C3 & C4 & \\
\hline 1 & Pegawai-A & 2 & 4 & 3 & 3 & \\
\hline 2 & Pegawai-B & 3 & 4 & 3 & 3 & \\
\hline 3 & Pegawai-C & 4 & 4 & 3 & 3 & \\
\hline 4 & Pegawai-D & 3 & 5 & 4 & 3 & \\
\hline 5 & Pegawai-E & 3 & 3 & 3 & 1 & \\
\hline \multicolumn{2}{|c|}{ Profil Jabatan } & 3 & 3 & 4 & 5 & \multirow{2}{*}{ Gap } \\
\hline 1 & Pegawai-A & -1 & 1 & -1 & -2 & \\
\hline 2 & Pegawai-B & 0 & 1 & -1 & -2 & \\
\hline 3 & Pegawai-C & 1 & 1 & -1 & -2 & \\
\hline 4 & Pegawai-D & 0 & 2 & 0 & -2 & \\
\hline 5 & Pegawai-E & 0 & 0 & -1 & -4 & \\
\hline
\end{tabular}


Citec Journal, Vol. 3, No. 4, Agustus 2016 - Oktober 2016

\subsubsection{Perhitungan Hasil Bobot Nilai Gap}

Setelah diperoleh Gap pada masing-masing pegawai, setiap profil pegawai diberi bobot nilai sesuai ketentuan pada Tabel 1 sesuai dengan Gap untuk masing-masing aspek yaitu penilaian umum, penguasaan bidang kerja dan prilaku yang ditunjukkan pada Tabel 5, Tabel 6 dan Tabel 7.

Tabel 5. Hasil Bobot Nilai Gap Penilaian Umum

\begin{tabular}{|c|c|c|c|c|c|c|c|c|}
\hline No & Pegawai & A1 & A2 & A3 & A4 & A5 & A6 & \\
\hline 1 & Pegawai-A & -1 & 0 & -1 & 0 & -2 & -1 & \multirow[t]{5}{*}{ Gap } \\
\hline 2 & Pegawai-B & 0 & 0 & -1 & 0 & -2 & 0 & \\
\hline 3 & Pegawai-C & 1 & 0 & -1 & 0 & 0 & 0 & \\
\hline 4 & Pegawai-D & 0 & 1 & 0 & 0 & 0 & 1 & \\
\hline 5 & Pegawai-E & 0 & -1 & -1 & -2 & -2 & 2 & \\
\hline \multicolumn{9}{|c|}{ Profil Jabatan } \\
\hline 1 & Pegawai-A & 4 & 5 & 4 & 5 & 3 & 4 & \multirow{5}{*}{$\begin{array}{c}\text { Nilai } \\
\text { Bobot } \\
\text { Gap }\end{array}$} \\
\hline 2 & Pegawai-B & 5 & 5 & 4 & 5 & 3 & 5 & \\
\hline 3 & Pegawai-C & 4.5 & 5 & 4 & 5 & 5 & 5 & \\
\hline 4 & Pegawai-D & 5 & 4.5 & 5 & 5 & 5 & 4.5 & \\
\hline 5 & Pegawai-E & 5 & 4 & 4 & 3 & 3 & 3.5 & \\
\hline
\end{tabular}

Tabel 6. Hasil Bobot Nilai Gap

\begin{tabular}{|c|c|c|c|c|c|c|}
\hline No & Pegawai & B1 & B2 & B3 & B4 & \\
\hline 1 & Pegawai-A & -1 & -1 & -2 & -1 & \multirow[t]{5}{*}{ Gap } \\
\hline 2 & Pegawai-B & 0 & -1 & -2 & -1 & \\
\hline 3 & Pegawai-C & 1 & -1 & -2 & -1 & \\
\hline 4 & Pegawai-D & 0 & 0 & -1 & -1 & \\
\hline 5 & Pegawai-E & 0 & -2 & -2 & -3 & \\
\hline \multicolumn{7}{|c|}{ Profil Jabatan } \\
\hline 1 & Pegawai-A & 4 & 4 & 3 & 4 & \multirow{5}{*}{$\begin{array}{c}\text { Nilai } \\
\text { Bobot Gap }\end{array}$} \\
\hline 2 & Pegawai-B & 5 & 4 & 3 & 4 & \\
\hline 3 & Pegawai-C & 4.5 & 4 & 3 & 4 & \\
\hline 4 & Pegawai-D & 5 & 5 & 4 & 4 & \\
\hline 5 & Pegawai-E & 5 & 3 & 3 & 2 & \\
\hline
\end{tabular}

Tabel 7. Hasil Bobot Nilai Gap Prilaku

\begin{tabular}{|c|c|c|c|c|c|c|}
\hline No & Pegawai & C1 & C2 & C3 & C4 & \multirow{2}{*}{ Gap } \\
\hline 1 & Pegawai-A & -1 & 1 & -1 & -2 & \multirow{2}{*}{} \\
\hline 2 & Pegawai-B & 0 & 1 & -1 & -2 & \\
\hline 3 & Pegawai-C & 1 & 1 & -1 & -2 & \\
\hline 4 & Pegawai-D & 0 & 2 & 0 & -2 & \\
\hline 5 & Pegawai-E & 0 & 0 & -1 & -4 & \\
\hline \multicolumn{7}{|c|}{ Profil Jabatan } \\
\hline 1 & Pegawai-A & 4 & 4.5 & 4 & 3 & \multirow{2}{*}{ Nilai Bobot Gap } \\
\hline 2 & Pegawai-B & 5 & 4.5 & 4 & 3 & \\
\hline 3 & Pegawai-C & 4.5 & 4.5 & 4 & 3 & \\
\hline 4 & Pegawai-D & 5 & 3.5 & 5 & 3 & \\
\hline 5 & Pegawai-E & 5 & 5 & 4 & 1 & \\
\hline
\end{tabular}




\subsubsection{Perhitungan dan Pengelompokan Core Factor dan Secondary Factor}

Setelah menentukan bobot nilai gap untuk ketiga aspek yaitu aspek Penilaian Umum, Penguasaan Bidang Kerja dan perilaku dengan cara yang sama. Kemudian tiap aspek dikelompokkan menjadi 2 (dua) kelompok yaitu kelompok Core Factor dan Secondary Factor.

\section{a. Penilaian Umum}

Pada aspek penlaian umum yang menjadi sub aspek core factor adalah disiplin administrasi (A2), keandalan (A3) dan semangat kerja (A5) sedangkan yang menjadi sub aspek secondary factor adalah disiplin kerja (A1), kedewasaan dan integritas pribadi (A4), komunikasi dan kerjasama (A6). Setelah melakukan pengelompokkan langkah berikutnya adalah mencari perhitungan dengan menggunakan persamaan 2 untuk core factor dan persamaan 3 untuk secondary factor yang datanya diambil dari tabel 5 yang hasilnya ditunjukkan pada Tabel 8 .

Tabel 8. Perhitungan Core Factor dan Secondary Factor Penilaian Umum

\begin{tabular}{|c|c|c|c|c|c|c|c|c|c|}
\hline No & Pegawai & A1 & A2 & A3 & A4 & A5 & A6 & NCF & NSF \\
\hline 1 & Pegawai-A & 4 & 5 & 4 & 5 & 3 & 4 & 4.00 & 4.33 \\
\hline 2 & Pegawai-B & 5 & 5 & 4 & 5 & 3 & 5 & 4.00 & 5.00 \\
\hline 3 & Pegawai-C & 4.5 & 5 & 4 & 5 & 5 & 5 & 4.67 & 4.83 \\
\hline 4 & Pegawai-D & 5 & 4.5 & 5 & 5 & 5 & 4.5 & 4.83 & 4.83 \\
\hline 5 & Pegawai-E & 5 & 4 & 4 & 3 & 3 & 3.5 & 3.67 & 3.83 \\
\hline
\end{tabular}

b. Penguasaan Bidang Kerja

Pada aspek penguasaan bidang kerja yang menjadi sub aspek core factor adalah kuantitas hasil kerja (B2), kualitas hasil kerja (B3) sedangkan yang menjadi sub aspek secondary factor adalah keteguhan pada prinsip kerja (B1), kepedulian terhadap organisasi (B4). Setelah melakukan pengelompokkan langkah berikutnya adalah mencari perhitungan dengan menggunakan persamaan 2 untuk core factor dan persamaan 3 untuk secondary factor yang datanya diambil dari Tabel 6 yang hasilnya ditunjukkan pada Tabel 9.

Tabel 9. Perhitungan Core Factor dan Secondary Factor Penguasaan Bidang Kerja

\begin{tabular}{|c|c|c|c|c|c|c|c|}
\hline No & Pegawai & B1 & B2 & B3 & B4 & NCF & NSF \\
\hline 1 & Pegawai-A & 4 & 4 & 3 & 4 & 3.50 & 4.00 \\
\hline 2 & Pegawai-B & 5 & 4 & 3 & 4 & 3.50 & 4.50 \\
\hline 3 & Pegawai-C & 4.5 & 4 & 3 & 4 & 3.50 & 4.25 \\
\hline 4 & Pegawai-D & 5 & 5 & 4 & 4 & 4.50 & 4.50 \\
\hline 5 & Pegawai-E & 5 & 3 & 3 & 2 & 3.00 & 3.50 \\
\hline
\end{tabular}

\section{c. Perilaku}

Pada aspek prilaku yang menjadi sub aspek core factor adalah keteguhan hati (C3) dan pemenuhan (C4) sedangkan yang menjadi sub aspek secondary factor adalah kekuasaan (C1) dan pengaruh (C2). Setelah melakukan pengelompokkan langkah berikutnya adalah mencari perhitungan dengan menggunakan persamaan 2 untuk core factor dan persamaan 3 untuk secondary factor yang datanya diambil dari tabel 6 yang hasilnya ditunjukkan pada Tabel 10. 
Citec Journal, Vol. 3, No. 4, Agustus 2016 - Oktober 2016

Tabel 10. Perhitungan Core Factor dan Secondary Factor Penguasaan Bidang Kerja

\begin{tabular}{|c|c|c|c|c|c|c|c|}
\hline No & Pegawai & C1 & C2 & C3 & C4 & NCF & NSF \\
\hline 1 & Pegawai-A & 4 & 4.5 & 4 & 3 & 3.50 & 4.25 \\
\hline 2 & Pegawai-B & 5 & 4.5 & 4 & 3 & 3.50 & 4.75 \\
\hline 3 & Pegawai-C & 4.5 & 4.5 & 4 & 3 & 3.50 & 4.50 \\
\hline 4 & Pegawai-D & 5 & 3.5 & 5 & 3 & 4.00 & 4.25 \\
\hline 5 & Pegawai-E & 5 & 5 & 4 & 1 & 2.50 & 5.00 \\
\hline
\end{tabular}

\subsubsection{Perhitungan Nilai Total}

Untuk mencari perhitungan nilai total menggunakan persamaan 4 yang hasilnya ditunjukkan pada Tabel 11, Tabel 12 dan Tabel 13 dengan nilai persen $60 \%$ untuk core factor dan $40 \%$ untuk secondary factor.

Tabel 11. Penilaian Umum

\begin{tabular}{|c|l|c|c|c|}
\hline No & \multicolumn{1}{|c|}{ Pegawai } & NCF & NSF & Ni \\
\hline 1 & Pegawai-A & 4.00 & 4.33 & 4.1 \\
\hline 2 & Pegawai-B & 4.00 & 5.00 & 4.40 \\
\hline 3 & Pegawai-C & 4.67 & 4.83 & 4.7 \\
\hline 4 & Pegawai-D & 4.83 & 4.83 & 4.8 \\
\hline 5 & Pegawai-E & 3.67 & 3.83 & 3.7 \\
\hline
\end{tabular}

Tabel 12. Penguasaan Bidang Kerja

\begin{tabular}{|c|l|c|c|c|}
\hline No & \multicolumn{1}{|c|}{ Pegawai } & NCF & NSF & Ni \\
\hline 1 & Pegawai-A & 3.50 & 4.00 & 3.70 \\
\hline 2 & Pegawai-B & 3.50 & 4.50 & 3.90 \\
\hline 3 & Pegawai-C & 3.50 & 4.25 & 3.80 \\
\hline 4 & Pegawai-D & 4.50 & 4.50 & 4.50 \\
\hline 5 & Pegawai-E & 3.00 & 3.50 & 3.20 \\
\hline
\end{tabular}

Tabel 13. Perilaku

\begin{tabular}{|c|l|c|c|c|}
\hline No & Pegawai & NCF & NSF & Ni \\
\hline 1 & Pegawai-A & 3.50 & 4.25 & 3.80 \\
\hline 2 & Pegawai-B & 3.50 & 4.75 & 4.00 \\
\hline 3 & Pegawai-C & 3.50 & 4.50 & 3.90 \\
\hline 4 & Pegawai-D & 4.00 & 4.25 & 4.10 \\
\hline 5 & Pegawai-E & 2.50 & 5.00 & 3.50 \\
\hline
\end{tabular}




\subsubsection{Perhitungan Penentuan Hasil Akhir/Ranking}

Perhitungan penentuan hasil akhir/ranking ditunjukkan pada Tabel 14 dengan menggunakan persamaan 5 dengan nilai $40 \%$ untuk penilaian umum, $40 \%$ untuk penguasaan bidang kerja dan $30 \%$ untuk perilaku.

Tabel 14. Penentuan Hasil Akhir

\begin{tabular}{|c|c|c|c|c|c|c|}
\hline No & Pegawai & $\begin{array}{c}\text { Ni (Penilaian } \\
\text { Umum) }\end{array}$ & $\begin{array}{c}\text { Ni (Penguasaan } \\
\text { Bidang Kerja) }\end{array}$ & $\begin{array}{c}\text { Ni } \\
(\text { Prilaku) }\end{array}$ & $\begin{array}{c}\text { Nilai } \\
\text { Akhir }\end{array}$ & Rangking \\
\hline 1 & Pegawai-A & 4.13 & 3.70 & 3.80 & 4.27 & 4 \\
\hline 2 & Pegawai-B & 4.40 & 3.90 & 4.00 & 4.52 & 3 \\
\hline 3 & Pegawai-C & 4.73 & 3.80 & 3.90 & 4.58 & 2 \\
\hline 4 & Pegawai-D & 4.83 & 4.50 & 4.10 & 4.96 & 1 \\
\hline 5 & Pegawai-E & 3.73 & 3.20 & 3.50 & 3.82 & 5 \\
\hline
\end{tabular}

Berdasarkan data yang ditunjukkan pada Tabel 14 dengan menggunakan metode profile matching dapat direkomendasikan bahwa pegawai-D yang layak untuk menduduki jabatan dikarenakan memiliki nilai tertinggi diatas standard yang telah ditentukan oleh pihak manajemen untuk menduduki jabatan tersebut.

\subsection{Analisis Hasil}

Berdasarkan percobaan yang dilakukan dengan masukkan data yang sama yaitu input data pegawai, kriteria dan bobot nilai untuk masing-masing kriteria, Data Penilaian kinerja pegawai dalam bidang penilaian umum, penguasaan bidang kerja dan prilaku, antara perhitungan yang dilakukan secara manual dan perhitungan yang dilakukan oleh sistem, menghasilkan hasil analisis yang sama.

\section{KESIMPULAN}

1. Dengan penerapan metode profile matching didalam sistem pendukung keputusan dalam proses penilaian kinerja pegawai sebagai evaluasi kinerja pegawai yang dapat digunakan dalam promosi kenaikan jabatan dimana sesuai nilai standard yang ditentukan oleh pihak manajemen dalam menduduki posisi jabatan di lingkungan Universitas Potensi Utama.

2. Perancangan sistem promosi kenaikan jabatan pegawai ini memberikan gambaran pada implementasi sistem.

3. Penelitian ini lebih menggambarkan tentang analisis serta perancangan proses promosi kenaikan jabatan berdasarkan evaluasi kinerja pegawai yang dilakukan oleh pihak kepegawaian yaitu meliputi Penilaian Umum Penilaian, Penguasaan Bidang Kerja dan Prilaku.

\section{SARAN}

Penelitian dapat dijadikan sebagai acuan dalam proses penilaian kinerja pegawai dan memberikan rekomendasi kepada pihak manajemen dalam promosi kenaikan jabatan dilingkungan Universitas Potensi Utama dan juga perlu adanya dukungan dari berbagai pihak yang terkait, sehingga sistem dapat berjalan dengan baik dan memberikan hasil yang maksimal. Agar penelitian ini lebih baik dalam proses menganalisis proses promosi kenaikan jabatan maka diperlukan dalam mengambil dan membanding hasil penelitian ini dengan penelitian yang terkait. 


\section{DAFTAR PUSTAKA}

[1] Dwijaya, I., F., 2010, Sistem Pendukung Keputusan Kenaikan Jabatan pada PT. Sysmex menggunakan Metode Profile Matching, Skripsi, Fakultas Teknik dan Ilmu Komputer Jurusan Teknik Informatika, Universitas Komputer Indonesia, Bandung.

[2] Muqtadir, A., Purdianto, I., 2013 Sistem Pendukung Keputusan Kenaikan Jabatan Menggunakan Metode Profile Matching (Studi Kasus di PT. Industri Kemasan Semen Gresik), Seminar Nasional Aplikasi Teknologi Informasi (SNATI), Yogyakarta, 15 Juni 2013.

[3] Hidayat, A. L., Pinandita, T., 2013, Sistem Pendukung Keputusan Evaluasi Kinerja Karyawan untuk Promosi Jabatan Struktural pada Bimbingan Belajar SCIENCEMASTER Menggunakan Metode GAP Kompetensi (Profile Matching), Jurnal Teknologi Technocientia, Vol. 5, No. 2, Hal 211-220

[4] Sabharwal, S., Sibal, R., Sharma, C., 2011, Applying Genetic Algorithm for Prioritization of Test Case Scenarios Derived from UML Diagrams. International Journal of Computer Science Issues (IJCSI), No. 2, Vol. 8, Hal. 433-444.

[5] Ananta, P. W., Winiarti, S., 2013, Sistem Pendukung Keputusan Dalam Penilaian Kinerja Pegawai untuk Kenaikan Jabatan Pegawai menggunakan Metode GAP Kompetensi (Studi Kasus Perusahaan Perkasa Jaya Compuretail), Jurnal Sarjana Teknik Informatika, No. 2, Vol. 1, Hal. 574-583.

[6] Kusrini, 2007, Konsep dan Aplikasi Sistem Pendukung Keputusan, Penerbit Andi, Yogyakarta.

[7] Suhartanto, R. J. B., Fanani, A. Z., 2014, Sistem Pendukung Keputusan Kenaikan Jabatan Berbasis Kompetensi pada PT. Valbury Asia Futures Semarang dengan metode Profile Matching, Skripsi, Fakultas Ilmu Komputer, Universitas Dian Nusantara, Semarang.

[8] Kusrini, Muchsin, A., 2006, Sistem Pendukung Keputusan Evaluasi Kinerja Karyawan untuk Promosi Jabatan, Prosiding Kopwil IV Volume II No 3, Kopertis Wilayah IV Jawa Barat dan Banten, Juli 2006

[9] Bahtiar, R. I., 2015, Sistem Pendukung Keputusan Promosi Kenaikan Jabatan pada PT Dua Kelinci Pati dengan Metode Profile Matching, Tugas Akhir, Fakultas Ilmu Komputer, Universitas Dian Nuswantoro, Semarang. 